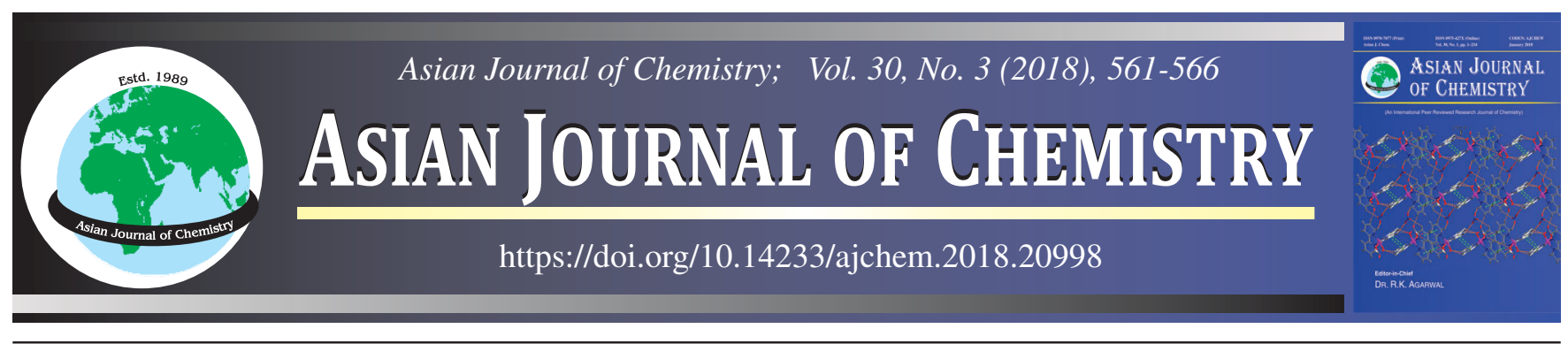

\title{
Kinetics Analysis of Reactions at Triple Phase Boundaries of Anode Supported Tubular Solid Oxide Fuel Cell
}

\author{
P. KALRA ${ }^{1, *}$, R.K. GARG ${ }^{2}$ and A. KUMAR ${ }^{3}$
}

${ }^{1}$ Department of Chemical Engineering, I.K. Gujral Punjab Technical University, Kapurthala-144 603, India

${ }^{2}$ Department of Chemical Engineering, Shaheed Bhagat Singh State Technical Campus, Ferozepur-152 004, India

${ }^{3}$ Department of Applied Science and Humanities, Shaheed Bhagat Singh State Technical Campus, Ferozepur-152 004, India

*Corresponding author: E-mail: pankajkalra75@gmail.com

Received: 22 August 2017;

Accepted: 17 October 2017;

Published online: 31 January 2018;

AJC-18744

Solid oxide fuel cells are solid-state ceramic cells, operating at a high temperature and recently been discovered one of the most efficient power generation devices causing no environmental pollution. In this paper, kinetic analysis study typical solid oxide fuel cell reactions has been done particularly methane steam reforming, water gas shift and electrochemical cell reactions on the active three phase boundaries of highly porous Ni-YSZ anode of an anode supported tubular solid oxide fuel cell. The reforming and water gas shift reactions occur in the gas phase due to the high temperature predominant in the solid oxide fuel cell leading to the production of hydrogen, $\mathrm{CO}_{\text {and }} \mathrm{CO}_{2}$. The hydrogen produced acts as a fuel for the solid oxide fuel cell reacts with $\mathrm{O}^{2-}$ ions at triple phase boundary forming water (steam) and $\mathrm{DC}$ current due to conventional electron flow from anode to cathode of solid oxide fuel cell. The variation of Gibb's free energy, equilibrium constant and rate of reactions has been represented and analyzed.

Keywords: Solid oxide fuel cell, Internal reforming, Methane reforming, Water gas shift, Ni-YSZ anode, Triple phase boundary.

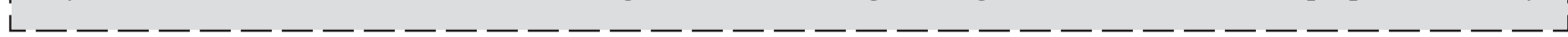

\section{INTRODUCTION}

At present, the world's bulk energy requirements are based on the combustion of fossil fuels, which causes air pollution, acid gas emissions and the emission of greenhouse gases. Fuel cell technology a source of clean energy production as it does not involve the typical hydrocarbon based combustion reaction $[1,2]$. A fuel cell is an electrochemical device that converts the chemical energy in fuels such as hydrogen (or hydrogenrich fuel like methane, butane) into electrical energy by exploiting the natural tendency of oxygen and hydrogen to react [1-4]. Solid oxide fuel cell is one type of solid-state ionic based fuel cell devices which have all its components in solid state and contains no moving parts. It consists of an electrolyte sandwiched between a porous anode and cathode, one of which may be thick enough to act as a support [1-3]. By controlling the means by which such a reaction occurs and directing the reaction through a device, it is possible to harvest the energy given off by the reaction. They operate at very high temperatures typically around $1,000{ }^{\circ} \mathrm{C}$ allowing them for on-board reforming of fuels without adding a reformer to the system [2-4]. They are not even poisoned by carbon monoxide, which can even be used as fuel along with hydrogen [1-3].
With advantages of high efficiencies, environmental friendliness and flexibility of usable fuel types, solid oxide fuel cells (SOFCs) have been considered as one of the most promising technologies for future electricity energy generation [1-5]. Since, knowledge of the actual elementary reaction steps and kinetics of electrochemical reactions taking place in a solid oxide fuel cell anode is critical for improvement of the anode's performance, the overall objective of this research was to investigate the mechanistic details of methane steam reforming, water gas shift electrochemical cell reactions in solid oxide fuel cell anodes. To achieve this objective, Ni/YSZ pattern anodes configured in tubular arrangement were used in the kinetics analysis study and as such a configuration of solid oxide fuel cell provides self-sealing mechanism.

\section{EXPERIMENTAL}

Principle of operation of tubular solid oxide fuel cell: Although many variations of solid oxide fuel cell designs are possible, such as tubular, planar and monolithic, tubular solid oxide fuel cells has a self-sealing mechanism, thereby does not require high temperature gas seals, although possesses lower power density and requires higher fabrication cost, still is one of the most favoured configuration $[1,3,4]$. In an anode- 
supported tubular solid oxide fuel cell, anode is sufficiently thick to serve as substrate layer employing thin electrolyte to reduce the ohmic resistance [5-7]. The tubular solid oxide fuel cell employed consisted of an annular cylindrical chamber, with the cathode forming the inner core and a thick anode support the outer one as shown in Fig. 1. The electrolyte lies between the two is very thin to reduce the ohmic resistance $[2,4,6]$. Air passes through the inner cathode channel whereas methane as fuel through the annular chamber contacting the Ni-YSZ anode. The electro-chemical reactions occur in the electrodes a distance of less than 10-20 $\mu$ from the electrolyte surface referred to as the functional layer $[1,8,9]$. The electrochemical reaction requires the co-existence of the electrolyte, the electron-conducting metal phase and the gas phase. This region is known as the triple-phase boundary $[1,10,11]$ (TPB). For a Ni/YSZ anodic material used in the study, the region between the electrolyte and the anode where the triple phase boundary exists is as shown in Fig. 2.

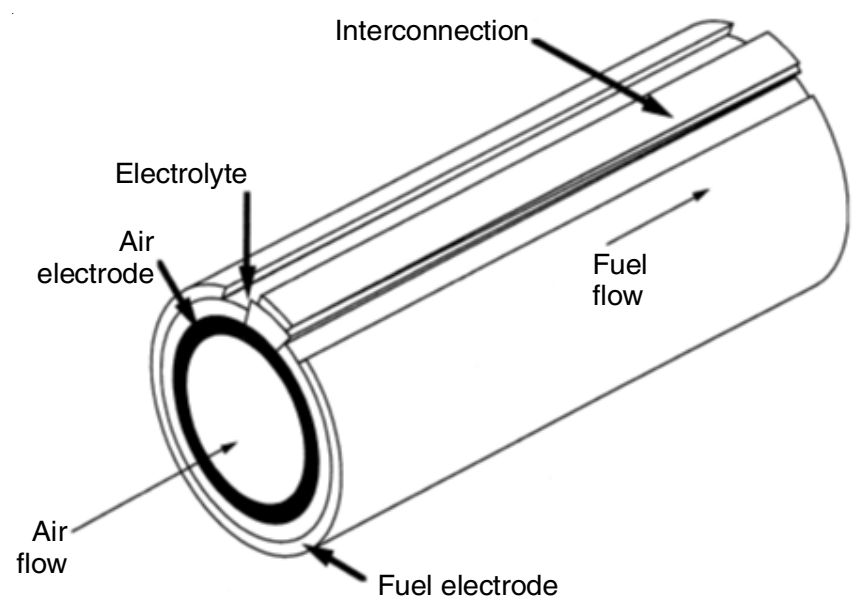

Fig. 1. Tubular solid oxide fuel cell used in the kinetic study (1)

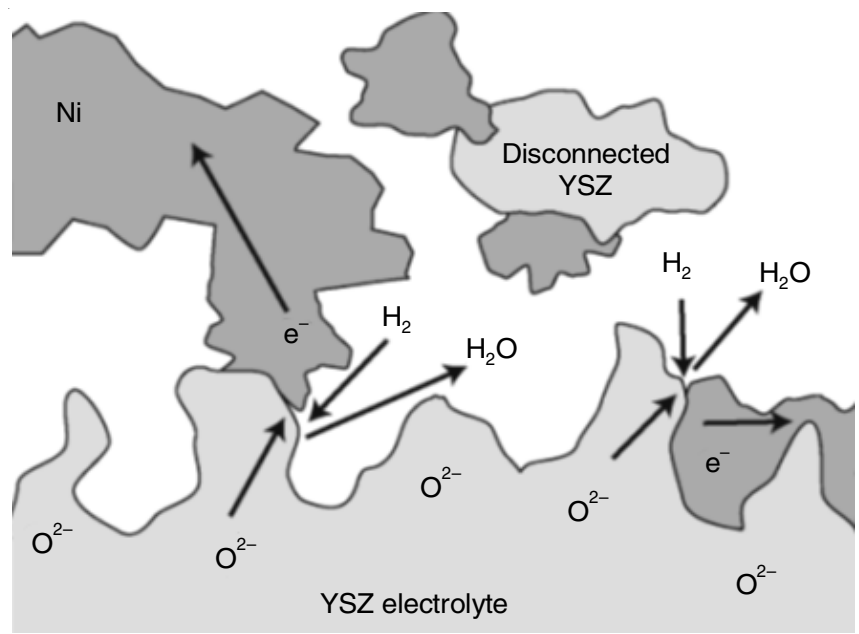

Fig. 2. Triple phase boundary for Ni-YSZ anode of solid oxide fuel cell (1)

\section{Kinetics aspects of solid oxide fuel cell:}

Reactions on the electrode surface a solid oxide fuel cell: At the electrode surface, electrochemical oxidation of $\mathrm{H}_{2}$ and $\mathrm{CO}$ occurs leading to generation of $\mathrm{e}^{-}$current from anode to cathode and a conventional current in the opposite direction.
Electrochemical oxidation of hydrogen: Hydrogen is adsorbed at the anode, ionized and the electrons are removed by the connection to the electrical load where the electrical work is used [11-13]. The first reaction on the anode is:

$$
\mathrm{H}_{2}(\mathrm{~g}) \longrightarrow 2 \mathrm{H}^{+}+2 \mathrm{e}^{-}
$$

Oxygen is adsorbed at the cathode connected with the load and ionized by the arriving electrons. The reaction that occurs on the cathode is

$$
1 / 2 \mathrm{O}_{2}(\mathrm{~g})+2 \mathrm{e}^{-} \longrightarrow \mathrm{O}^{2-}
$$

The oxide ions $\mathrm{O}^{2-}$ are conducted through the electrolyte and arrives at the anode. The $\mathrm{H}^{+}$and the oxide ion form a molecule of water according to the reaction:

$$
2 \mathrm{H}^{+}+\mathrm{O}^{2-} \longrightarrow \mathrm{H}_{2} \mathrm{O}(\mathrm{g})
$$

The overall electrochemical reaction [12-14] leading to oxidation of $\mathrm{H}_{2}$ reaction can thus be represented as:

$$
\mathrm{H}_{2}(\mathrm{~g})+1 / 2 \mathrm{O}_{2}(\mathrm{~g}) \longrightarrow \mathrm{H}_{2} \mathrm{O}(\mathrm{g})
$$

Electrochemical oxidation of carbon monoxide: The electrochemical oxidation of carbon monoxide follows similar mechanism as the electrochemical oxidation of hydrogen, the overall reaction being represented as:

$$
\mathrm{CO}(\mathrm{g})+\frac{1}{2} \mathrm{O}_{2}(\mathrm{~g}) \longrightarrow \mathrm{CO}_{2}(\mathrm{~g})
$$

It is generally thought that for a gas mixture containing $\mathrm{CO}$ and $\mathrm{H}_{2}$, electro-oxidation of $\mathrm{H}_{2}$ dominates over that of CO. In fact, it has been reported that approximately $98 \%$ of the current is a result of the electrochemical conversion of hydrogen [1214].

\section{Reactions in fuel channel}

Reforming reactions: In natural gas fuelled solid oxide fuel cells the gas enters the flow-channel pre-reformed and contains at least $\mathrm{CH}_{4}, \mathrm{H}_{2}, \mathrm{CO}, \mathrm{H}_{2} \mathrm{O}$ and $\mathrm{CO}_{2}$. Although much of the reforming is expected to occur in the electrode, most of steam reforming does occur in the fuel channel $[14,15]$. The steam reforming reaction is often assumed to have fast kinetics and modelled via local equilibrium assumption [14,15]. It has been reported that at $1173 \mathrm{~K}$, the steam reforming occurs 42 times faster than the electrochemical reaction of hydrogen.

Partial methane steam reforming reaction: Methane gets partially reformed at high temperature conditions prevailing there leading to formation of $\mathrm{CO}$ and $\mathrm{H}_{2}$ as per the following reaction $[14,15]$ :

$$
\mathrm{CH}_{4}(\mathrm{~g})+\mathrm{H}_{2} \mathrm{O}(\mathrm{g}) \rightleftharpoons 3 \mathrm{H}_{2}(\mathrm{~g})+\mathrm{CO}(\mathrm{g})
$$

$\Delta \mathrm{H}_{298 \mathrm{~K}}=206 \mathrm{KJ} / \mathrm{mol}$.

Complete methane steam reforming reaction: In excess of steam, complete reforming of methane occurs leading to formation of $\mathrm{CO}_{2}$ and $\mathrm{H}_{2}$ as per the following reaction $[14,15]$ :

$$
\mathrm{CH}_{4}(\mathrm{~g})+2 \mathrm{H}_{2} \mathrm{O}(\mathrm{g}) \rightleftharpoons 4 \mathrm{H}_{2}(\mathrm{~g})+\mathrm{CO}_{2}(\mathrm{~g})
$$

$\Delta \mathrm{H}_{298 \mathrm{~K}}=-41 \mathrm{KJ} / \mathrm{mol}$.

Water-gas shift reaction: The $\mathrm{CO}$ formed due to reforming reactions participates in the water-gas shift reaction and further affects the concentration of hydrogen at the reaction sites $[16,17]$.

$$
\mathrm{CO}(\mathrm{g})+\mathrm{H}_{2} \mathrm{O}(\mathrm{g}) \rightleftharpoons \mathrm{CO}_{2}(\mathrm{~g})+\mathrm{H}_{2}(\mathrm{~g})
$$

$\Delta \mathrm{H}_{298 \mathrm{~K}}=165 \mathrm{KJ} / \mathrm{mol}$. 
Bourdouard reaction: The formation of carbon is important because carbon can have a negative effect on the reactive area of the anode [18]. It leads to the formation of soot i.e. carbon which is detrimental to the working of solid oxide fuel cell.

$$
2 \mathrm{CO}(\mathrm{g}) \rightleftharpoons \mathrm{CO}_{2}(\mathrm{~g})+\mathrm{C}(\mathrm{s})
$$

Kinetics of chemical reactions is a strong function of temperature, it is important to model the temperature profile correctly. However, coupling the energy equation with the chemical kinetics is a challenge. For instance, steam reforming is an endothermic reaction while partial oxidation reforming and the water shift reaction are exothermic [12-15]. These reactions should be incorporated into the model as species and energy sources and sinks preformed an solid oxide fuel cell model where the temperature in the fuel cell was coupled to the temperature in the endothermic reformer.

\section{Modeling kinetics of reactions in the anode supported tubular solid oxide fuel cell}

Model assumptions: The simplifying assumptions while deriving the axially symmetrical steady state kinetic model of tubular solid oxide fuel cell were: (a). Steady-state conditions were presumed in the solid oxide fuel cell (b). Fuel and oxidant are ideal gas mixtures (c). Material of electrodes is homogeneous and isotropic (d). Concentration, temperature and rate of reaction does not vary in radial and angular direction.

Kinetics analysis of reactions: The rates in $\mathrm{mol} /$ (h.gcat)of reforming and water gas shift reactions are surface reactions being catalyzed by nickel are characterized by the following equations [15-17]:

$$
\begin{gathered}
\mathrm{r}_{\mathrm{MR} 1}=\frac{1}{\mathrm{DEN}^{2}} \frac{\mathrm{k}_{1}}{\mathrm{P}_{\mathrm{H}_{2}}^{2.5}}\left(\mathrm{P}_{\mathrm{CH}_{4}} \mathrm{P}_{\mathrm{H}_{2} \mathrm{O}}-\frac{\mathrm{P}_{\mathrm{H}_{2}}^{3} \mathrm{P}_{\mathrm{CO}}}{\mathrm{K}_{\mathrm{eqMR} 1}}\right) \\
\mathrm{r}_{\mathrm{WGS}}=\frac{1}{\mathrm{DEN}^{2}} \frac{\mathrm{k}_{2}}{\mathrm{P}_{\mathrm{H}_{2}}}\left(\mathrm{P}_{\mathrm{CO}} \mathrm{P}_{\mathrm{H}_{2} \mathrm{O}}-\frac{\mathrm{P}_{\mathrm{H}_{2}} \mathrm{P}_{\mathrm{CO}_{2}}}{\mathrm{~K}_{\mathrm{eqWGS}}}\right) \\
\mathrm{rEN}=1+\mathrm{K}_{\mathrm{CO}} \mathrm{P}_{\mathrm{CO}}+\mathrm{K}_{\mathrm{H}_{2}} \mathrm{P}_{\mathrm{H}_{2}}+\mathrm{K}_{\mathrm{CH}_{4}} \mathrm{P}_{\mathrm{CH}_{4}}+\mathrm{K}_{\mathrm{H}_{2} \mathrm{O}} \frac{\mathrm{P}_{\mathrm{H}_{2} \mathrm{O}}}{\mathrm{P}_{\mathrm{H}_{2}}}\left(\mathrm{P}_{\mathrm{CH}_{4}} \mathrm{P}_{\mathrm{H}_{2} \mathrm{O}}^{2}-\frac{\mathrm{P}_{\mathrm{H}_{2}}^{4} \mathrm{P}_{\mathrm{CO}_{2}}}{\mathrm{~K}_{\mathrm{eqMR} 2}}\right) \\
\mathrm{k}_{\mathrm{i}}=\mathrm{A}_{\mathrm{i}} \exp \left(\frac{-\mathrm{E}_{\mathrm{act}, \mathrm{i}}}{\mathrm{RT}}\right) \\
\mathrm{K}_{\mathrm{j}}=\mathrm{B}_{\mathrm{j}} \exp \left(\frac{\Delta \mathrm{H}_{\mathrm{j}}}{\mathrm{RT}}\right)
\end{gathered}
$$

The kinetics parameters for different reactions and adsorption constants for various components for the rate equations are given in Tables 1 and 2, respectively.
TABLE-1

KINETICS PARAMETERS [Ref. 15]

\begin{tabular}{lcc}
\multicolumn{1}{c}{ Reaction (i) } & $\begin{array}{c}\mathrm{A}_{\mathrm{i}}\left[\mathrm{mol} \mathrm{MPa}^{0.5}\right. \\
\left(\mathrm{gcat}^{-1}(\mathrm{~h})^{-1}\right]\end{array}$ & $\begin{array}{c}\mathrm{E}_{\text {act, } \mathrm{I}} \\
\left(\mathrm{KJ} \mathrm{mol}^{-1}\right)\end{array}$ \\
\hline Partial methane reforming (1) & $1.336 \times 10^{15}$ & 240.1 \\
Water gas shift reaction (2) & $1.995 \times 10^{7}$ & 67.13 \\
Complete methane reforming (3) & $3.226 \times 10^{14}$ & 243.9 \\
\hline
\end{tabular}

TABLE-2

ADSORPTION CONSTANTS [Ref. 15]

\begin{tabular}{lcc}
\multicolumn{1}{c}{ Gaseous component $(\mathrm{j})$} & $\mathrm{Bj}\left(\mathrm{MPa}^{-1}\right)$ & $\Delta \mathrm{H}_{\mathrm{J}}\left(\mathrm{KJ} \mathrm{mol}^{-1}\right)$ \\
\hline Carbon monoxide $(\mathrm{CO})$ & $8.23 \times 10^{-4}$ & -70.65 \\
Hydrogen $\left(\mathrm{H}_{2}\right)$ & $6.12 \times 10^{-8}$ & -82.90 \\
Water $\left(\mathrm{H}_{2} \mathrm{O}\right)$ & $1.77 \times 10^{5}$ & 88.68 \\
Methane $\left(\mathrm{CH}_{4}\right)$ & $6.65 \times 10^{-3}$ & -38.28 \\
\hline
\end{tabular}

The solid oxide fuel cell under investigation is fed by air, with the typical atmospheric air composition and by the fuel as per the composition given in Table-3. Thus, the fuel stream consists of methane and nitrogen included in the system inlet fuel, which is typically the natural gas and also of $\mathrm{CO}, \mathrm{CO}_{2}$, $\mathrm{H}_{2}$ and $\mathrm{H}_{2} \mathrm{O}$ produced by the steam methane reforming reactions.

Since, the current density has been assumed to be fixed in this simulation, the rate of reaction for $\mathrm{H}_{2}$ becomes equal to the rate of cell reaction for a particular value of current density $[12,13]$ and is given by:

$$
\mathrm{r}_{\mathrm{CR}}=\frac{\mathrm{iA} \text { cell }}{2 \mathrm{~F}}
$$

The rate of oxygen consumed at the cathode according to stoichiometry therefore becomes $[12,13]$ :

$$
\mathrm{r}_{\mathrm{O}_{2}}=\frac{\mathrm{iA}_{\text {cell }}}{4 \mathrm{~F}}
$$

Applying finite element method, the overall conservation equations for different components are:

$$
\begin{aligned}
\mathrm{r}_{\mathrm{H}_{2}} & =\mathrm{r}_{\mathrm{MR}_{1}}+\mathrm{r}_{\mathrm{WGS}}-\mathrm{r}_{\text {Cell reaction }}+\mathrm{r}_{\mathrm{MR}_{2}} \\
= & \mathrm{r}_{\mathrm{MR}_{1}}+r_{\mathrm{WGS}}-\frac{\mathrm{I}_{\mathrm{H}_{2}}}{2 \mathrm{~F}}+\mathrm{r}_{\mathrm{MR}_{2}} \\
\mathrm{r}_{\mathrm{H}_{2} \mathrm{O}} & =-\mathrm{r}_{\mathrm{MR}_{1}}-\mathrm{r}_{\mathrm{WGS}}+\mathrm{r}_{\text {Cell reaction }}-2 \mathrm{r}_{\mathrm{MR}_{2}} \\
& =-\mathrm{r}_{\mathrm{MR}_{1}}-\mathrm{r}_{\mathrm{WGS}}+\frac{\mathrm{I}_{\mathrm{H}_{2}}}{2 \mathrm{~F}}-2 \mathrm{r}_{\mathrm{MR}_{2}} \\
\mathrm{r}_{\mathrm{CO}} & =\mathrm{r}_{\mathrm{MR}_{1}}-\mathrm{r}_{\mathrm{WGS}}+\mathrm{r}_{\mathrm{CO} \text { oxidation }}-2 \mathrm{r}_{\mathrm{BR}} \\
& =\mathrm{r}_{\mathrm{MR}_{1}}-\mathrm{r}_{\mathrm{WGS}_{\mathrm{GS}}}-\frac{\mathrm{I}_{\mathrm{CO}}}{2 \mathrm{~F}}+\mathrm{r}_{\mathrm{BR}} \\
\mathrm{r}_{\mathrm{CO}_{2}} & =\mathrm{r}_{\mathrm{WGS}}+\mathrm{r}_{\mathrm{MR}_{2}}+\mathrm{r}_{\mathrm{CO} \text { oxidation }}+\mathrm{r}_{\mathrm{BR}} \\
& =\mathrm{r}_{\mathrm{WGS}}+\mathrm{r}_{\mathrm{MR}_{2}}+\frac{\mathrm{I}_{\mathrm{CO}}}{2 \mathrm{~F}}+\mathrm{r}_{\mathrm{BR}} \\
\mathrm{r}_{\mathrm{CH}_{4}} & =-\mathrm{r}_{\mathrm{MR}_{1}}-\mathrm{r}_{\mathrm{MR}_{2}}
\end{aligned}
$$

TABLE-3

MOLAR FLOW RATES OF THE INLET STREAMS (kmol/s) [Ref. 16]

\begin{tabular}{cccccccc} 
Component & $\mathrm{CH}_{4}$ & $\mathrm{CO}$ & $\mathrm{H}_{2}$ & $\mathrm{H}_{2} \mathrm{O}$ & $\mathrm{O}_{2}$ & $\mathrm{CO}_{2}$ & $\mathrm{~N}_{2}$ \\
\hline Air stream & - & - & - & - & $9.24 \times 10^{-6}$ & - & $3.48 \times 10^{-5}$ \\
Fuel stream & $1.48 \times 10^{-7}$ & $1.68 \times 10^{-7}$ & $5.04 \times 10^{-7}$ & $4.05 \times 10^{-7}$ & - & $2.77 \times 10^{-7}$ & $9.82 \times 10^{-9}$ \\
\hline
\end{tabular}




\section{RESULTS AND DISCUSSION}

The reaction kinetics for tubular one-dimensional were analyzed and a case study was performed. The tubular solid oxide fuel cell was considered to be operating with a full internal reforming, which balances the heat being generated by electrochemical cell reaction and water gas shift reaction. The temperature varied throughout the solid oxide fuel cell leading to a variation of $\Delta \mathrm{G}$ values for methane reforming and water gas shift reactions.

The negative values of $\Delta \mathrm{G}$ clearly depicted in Fig. 3 possessed by both the demethanation reactions shows the high value of spontaneity of these reactions at the conditions. These negative values decreases which increases in moving axially through the solid oxide fuel cell owing to the drop in temperature.

On the other hand, the water gas shift reaction, an exothermic reaction proceed with a positive value of $\Delta \mathrm{G}$, thereby nonspontaneous at this high temperature. The $\Delta \mathrm{G}$ values decreases due to a decrease in temperature in moving along the solid oxide fuel cell.

Fig. 4 depicts the variation of equilibrium constant along the axis of tubular solid oxide fuel cell. Equilibrium constants for demathanation reactions which are endothermic in nature, decreases slightly along the axis owing to a small decrease in temperature in axial direction from the inlet to the outlet. as well as water gas shift increases along the length due to a slight overall decrease in temperature. $\mathrm{K}_{\mathrm{eq}}$ for demathanation reactions has a large value $>1000$ owing to the large tendency of reactions in the forward direction.

Equilibrium constant $\mathrm{K}_{\mathrm{eq}}$ for water gas shift reaction increases only very slightly along the axis due to a very small order of magnitude exothermic nature of the reaction. Moreover, $\mathrm{K}_{\mathrm{eq}}$ value is $<1$, thereby the reaction proceeds more in the backward direction at the conditions of system.
Reaction kinetics simulation was performed for a onedimensional tubular solid oxide fuel cell, operating with a full internal reforming using the heat being generated by the exothermic electrochemical cell reaction and water gas shift reaction and a case study was performed. The variation of rates of reaction for various reactions has been illustrated in Fig. 5.

The rate of cell reaction remains constant along the length of tubular solid oxide fuel cell owing to the constant current density assumption used in the kinetic analysis. As the cell reaction rate, just depends on the current density developed alone, the flat graph parallel to axial length in Fig. 5(a) supports this point of view.

The rates at which methane gets reformed decreases along the axis of tubular solid oxide fuel cell. The reforming kinetics illustrates that rate of these reactions are linearly related to concentrations of both of the gaseous reactants $\mathrm{CH}_{4}$ and $\mathrm{H}_{2} \mathrm{O}$. Although the concentration of $\mathrm{H}_{2} \mathrm{O}$ should increases along the axis of solid oxide fuel cell due to its formation by electrochemical cell reaction, a decrease in concentration of primary reactant i.e. $\mathrm{CH}_{4}$ leads to a marginal decrease in the rate of these reactions clearly depicted in Fig. 5(d).

The water gas shift reaction has a negative rate corresponding to the conditions prevalent in the solid oxide fuel cell. The negativity of the rate of reaction increases owing to an increase in concentration of $\mathrm{H}_{2}$ and $\mathrm{CO}_{2}$ along the solid oxide fuel cell [19-22].

\section{Conclusion}

The paper presents an original approach for the finitevolume axial-symmetric reaction kinetic analysis of a tubular solid oxide fuel cell. The kinetic model presented accurate calculation of the main chemical and electrochemical phenomena occurring in the tubular solid oxide fuel cell. The rates

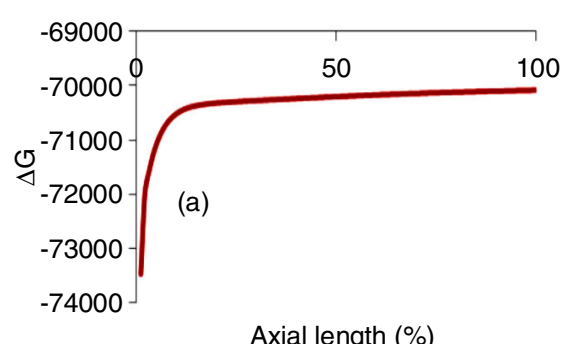

Axial length (\%)
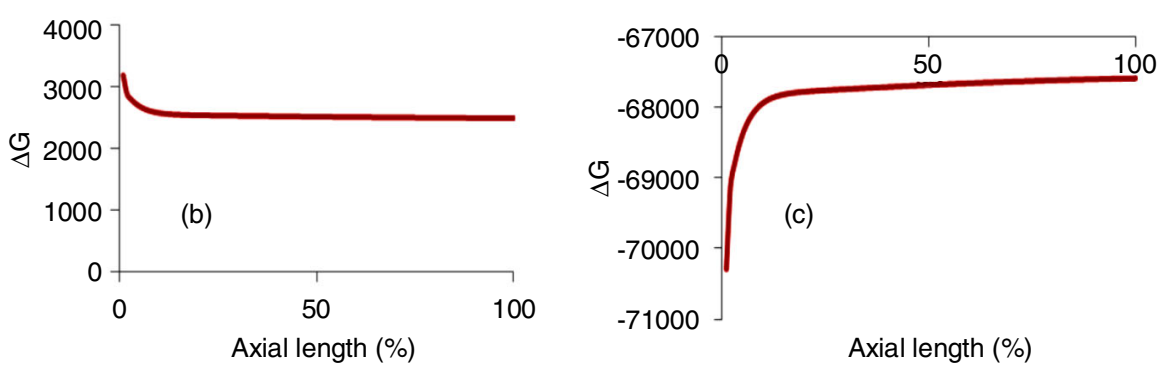

Fig. 3. Axial variation of $\Delta \mathrm{G}$ for (a) partial reforming of methane, (b) Water gas shift reaction, WGS, (c) Complete reforming of methane
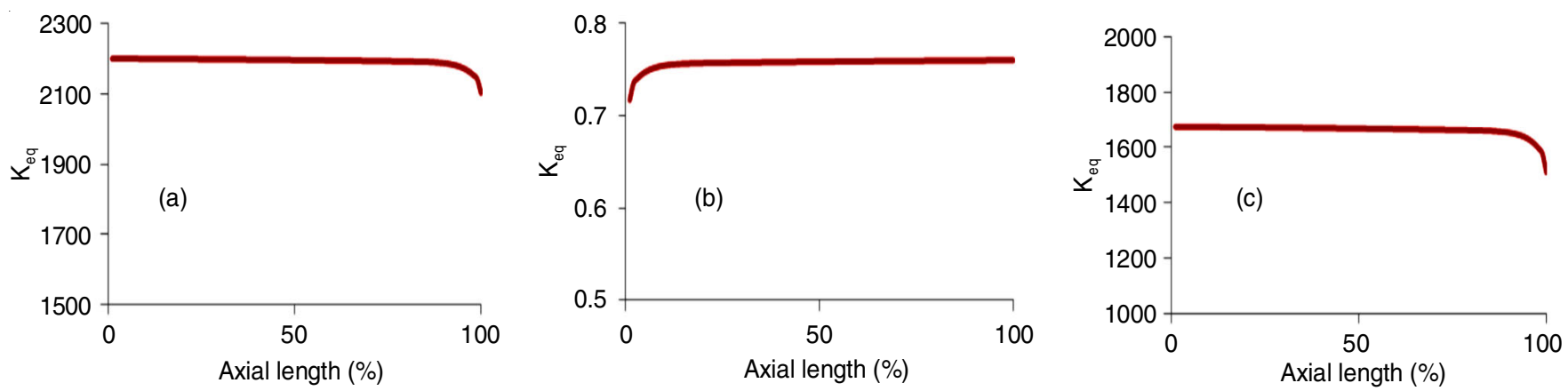

Fig. 4. Axial variation of $\mathrm{K}_{\mathrm{eq}}$ for (a) partial reforming of methane, (b) water gas shift reaction (WGS), (c) complete reforming of methane 

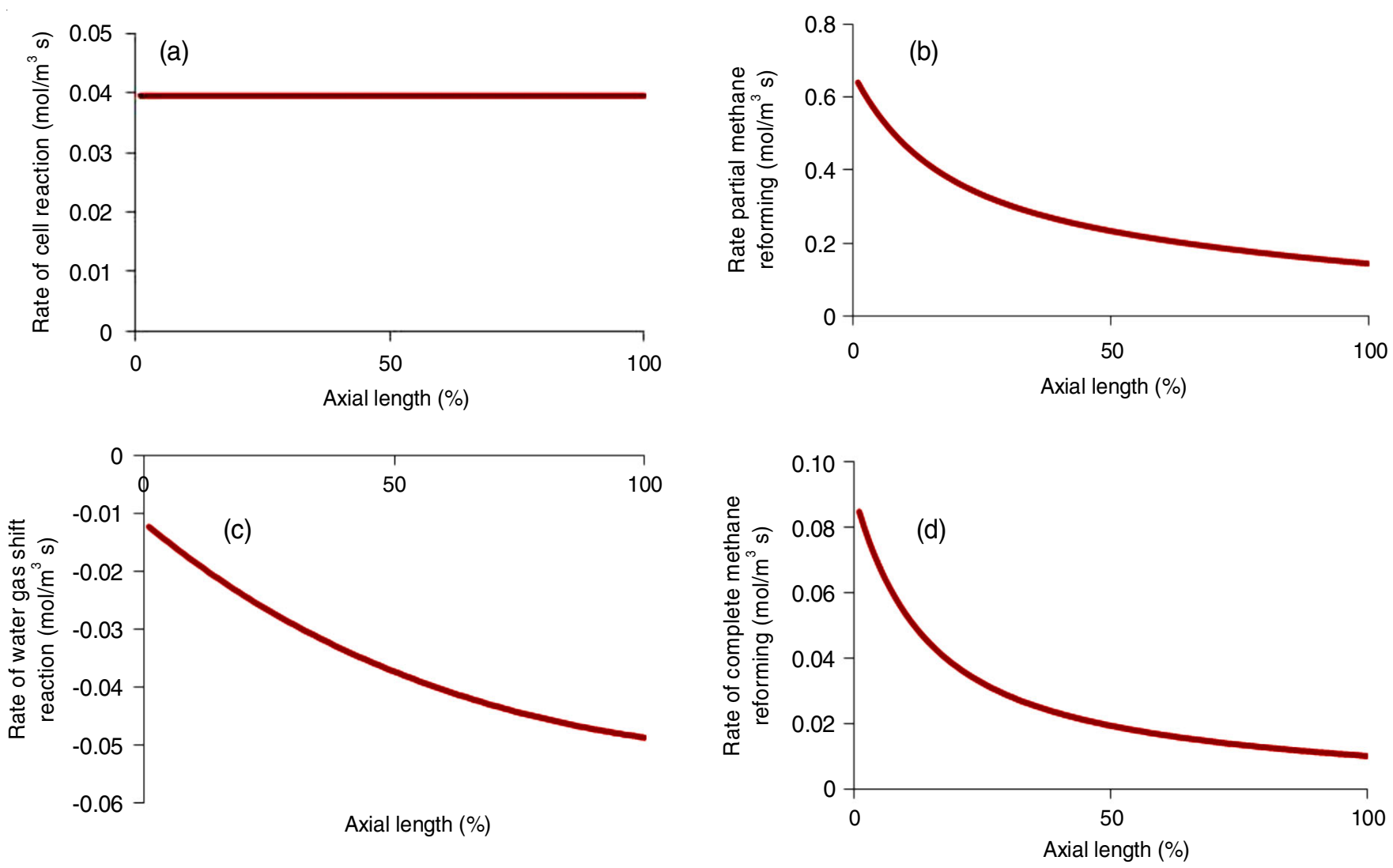

Fig. 5. Variation of rate of reaction along the axis, (a) cell reaction, (b) partial methane reforming reaction, (c) water gas shift reaction, (d) complete methane reforming reaction

of reaction along the solid oxide fuel cell axis were analyzed to note the trend of the chemical and electrochemical phenomena occurring in the solid oxide fuel cell tube. It was found that in the first part of the tubular solid oxide fuel cell the internal steam reforming process is pre-dominant over the electrochemical reaction, inducing an increase of the hydrogen partial pressure. Conversely, in the same section the steam partial pressure decreases, because the amount of water used by the internal reforming process is much higher than the one released by the electrochemical process. Then, the steam reforming reactions quickly approach the equilibrium conditions and then subsequently begin to increase. Clearly, the higher the demethanization rate, the higher is the amount of heat required by the pre-reforming process. The rate of reforming reactions is clearly much faster than the rate of the shift reaction, not equilibrium controlled as usually assumed. In fact, in the first part of the solid oxide fuel cell tube, the reforming process is faster than the electrochemical one. Then, the reforming reactions reach very quickly to the equilibrium conditions (rates of reaction asymptotically approaching zero), whereas the electrochemical reaction continues to occur,

The simulation model presented allowed accurate calculation of the main, chemical and electrochemical properties in the system, such as Gibb's free energy, equilibrium constant, rates of reactions, etc. The results showed that some of the simplifying assumptions usually adopted in solid oxide fuel cell simulations are not rigorously acceptable, but still the model and the simulated results were in concordance with that predicted from theoretical analysis. The one-dimensional modelling can further be extended to multi-dimensional by taking variation of properties along the radial direction, although the variation along the angular direction $\theta$ still can be safely ignored.

\section{REFERENCES}

1. P. Kalra, R.K. Garg and A. Kumar, Solid Oxide Fuel Cell-A Future Source of Power and Heat Generation, Engineering Applications of Nanoscience and Nanomaterials, Special edition of Material Science Forum, Trans Tech Publications, Switzerland, vol. 757, pp. 217-241 (2013).

2. S.C. Singhal and K. Kendall, High Temperature Solid Oxide Fuel Cells: Fundamentals, Design and Applications, Elsevier Science (2003).

3. S.C. Singhal, Solid State Ion., 152-153, 405 (2002); https://doi.org/10.1016/S0167-2738(02)00349-1.

4. S.C. Singhal, Solid State Ion., 135, 305 (2000); https://doi.org/10.1016/S0167-2738(00)00452-5.

5. N. Laosiripojana, W. Wiyaratn, W. Kiatkittipong, A. Arpornwichanop, A. Soottitantawat and S. Assabumrungrat, Eng. J. (N.Y.), 13, 65 (2009); https://doi.org/10.4186/ej.2009.13.1.65.

6. N.P. Brandon, Materials Engineering for Solid Oxide Fuel Cell Technology, Materials Science Forum, Trans Tech Publications, Switzerland vols. 539-543, pp 20-27 (2007).

7. H. Mahcene, H. Ben-Moussa, H. Bouguetaia, B. Bouchekima and D. Bechki, Fuel Cells J., (2006).

8. S. McIntosh and R.J. Gorte, Chem. Rev., 104, 4845 (2004); https://doi.org/10.1021/cr020725g.

9. M. Lo Faro, D. La Rosa, V. Antonucci and A.S. Arico, J. Indian Inst. Sci., 89, 363 (2009).

10. A. Atkinson, S. Barnett, R.J. Gorte, J.T.S. Irvine, A.J. McEvoy, M. Mogensen, S.C. Singhal and J. Vohs, Nat. Mater, 3, 17 (2004); https://doi.org/10.1038/nmat1040.

11. P. Kalra, R.K. Garg and A. Kumar, J. Energy Technol. Policy, 5, 76 (2015).

12. P. Kalra, R.K. Garg and A. Kumar, Indian J. Sci. Technol., 10, 1 (2017); https://doi.org/10.17485/ijst/2017/v10i19/113661. 
13. P. Kalra, R.K. Garg and N.K. Grover, Int. J. Chemtech Res., 10, 784 (2017).

14. U. Pasaogullari and C.Y. Wang, Proc. ECS, 07, 1403 (2003).

15. F. Gallucci, L. Paturzo and A. Basile, Int. J. Hydrogen Energy, 29, 611 (2004); https://doi.org/10.1016/j.ijhydene.2003.08.003.

16. F. Calise, M. Dentice d'Accadia, A. Palombo and L. Vanoli, Int. J. Thermodyn., 10, 87 (2007).

17. F. Calise, M. Dentice d'Accadia, A. Palombo and L. Vanoli, J. Fuel Cell Sci. Technol., 5, 021014 (2008); https://doi.org/10.1115/1.2784296.

18. M. Andersson, J. Yuan and B. Sundén, Appl. Energy, 87, 1461 (2010); https://doi.org/10.1016/j.apenergy.2009.11.013.
19. J. Yuan, Chem. Prod. Process Model., 5, Article 12 (2010); https://doi.org/10.2202/1934-2659.1450.

20. S.Z. Abbas, V. Dupont and T. Mahmud, Int. J. Hydrogen Energy, 42, 18910 (2017);

https://doi.org/10.1016/j.ijhydene.2017.05.222.

21. E.S. Hecht, G.K. Gupta, H. Zhu, A.M. Dean, R.J. Kee, L. Maier and O. Deutschmann, Appl. Catal. A, 295, 40 (2005); https://doi.org/10.1016/j.apcata.2005.08.003

22. L. Chibane and B. Djellouli, Int. J. Chem. Eng. Appl., 2, 147 (2011); https://doi.org/10.7763/IJCEA.2011.V2.93. 